\title{
FLAT-LINING OR SEETHING BENEATH THE SURFACE? TWO DECADES OF CHANGING ECONOMIC INEQUALITY IN THE UK
}

\author{
Polina Obolenskaya and John Hills ${ }^{1}$
}

\section{INTRODUCTION}

The United Kingdom (UK) is well-known as one of the more economically unequal industrialised countries (OECD, 2015). It is commonly perceived that inequalities have increased in recent years. The economic and financial turmoil from 2008 is an obvious engine, as are the subsequent fall and then very slow recovery in real wages (Clarke and Gregg, 2018), the austerity policies of the 2010 Coalition and then Conservative governments, and rapid growth in the biggest fortunes after the initial impact of the crisis (Sunday Times, 2018). Assumed inequality growth, and the ways some people and areas have therefore been 'left behind', have been blamed for recent political dramas, including the 2016 Brexit vote.

But even in aggregate, the picture is more nuanced. Figure 1 presents trends since 1970 in four income inequality measures - the Gini coefficients and 90:10 ratios derived by the Institute for Fiscal Studies from the Family Expenditure Survey (FES) and Family Resources Survey (FRS), measured both before and after allowing for housing costs. ${ }^{2}$ The figure reminds us that the big changes in UK income inequality were a generation ago, mainly under Mrs Thatcher in the 1980s. ${ }^{3}$

\footnotetext{
${ }^{1}$ Polina Obolenskaya is a Research Officer at the Centre for Analysis of Social Exclusion (CASE) and John Hills is Richard Titmuss Professor of Social Policy, both at the London School of Economics and Political Science. This work was supported by the Nuffield Foundation through CASE's 'Social Policy and Distributional Outcomes' (SPDO) programme. The authors are very grateful to Eleni Karagiannaki for advice and design of the STATA 'Inequalities Program' developed for the SPDO programme and used in the underlying analysis. This estimates outcomes by characteristic for each year, and tests for differences between groups and changes over time (Karagiannaki, forthcoming). They are also grateful to Kritty Treebhoohun for research support, and to Tania Burchardt, Kerris Cooper, Howard Glennerster, Abigail McKnight, Brian Nolan, Polly Vizard, the editors of the Review, and two anonymous referees for comments and suggestions on earlier drafts.

${ }^{2}$ With adjustment for incomes of the top 1 per cent based on tax data. See Burkhauser, et al. (2018) for alternative adjustments suggesting that overall income inequality grew faster before the crisis but then fell more than shown in the official series.

${ }^{3}$ The income share of the top 1 per cent from tax data moved differently, with a continuing rise to a peak of nearly 15 per cent in 2008-09, compared to under 6 per cent in the late 1970s, but then fell back after the crisis (World Inequality Database, https://wid.world/data/).
} 


\section{Figure 1: Trends in aggregate income inequality, 1970 to 2016-17 (GB/UK)}

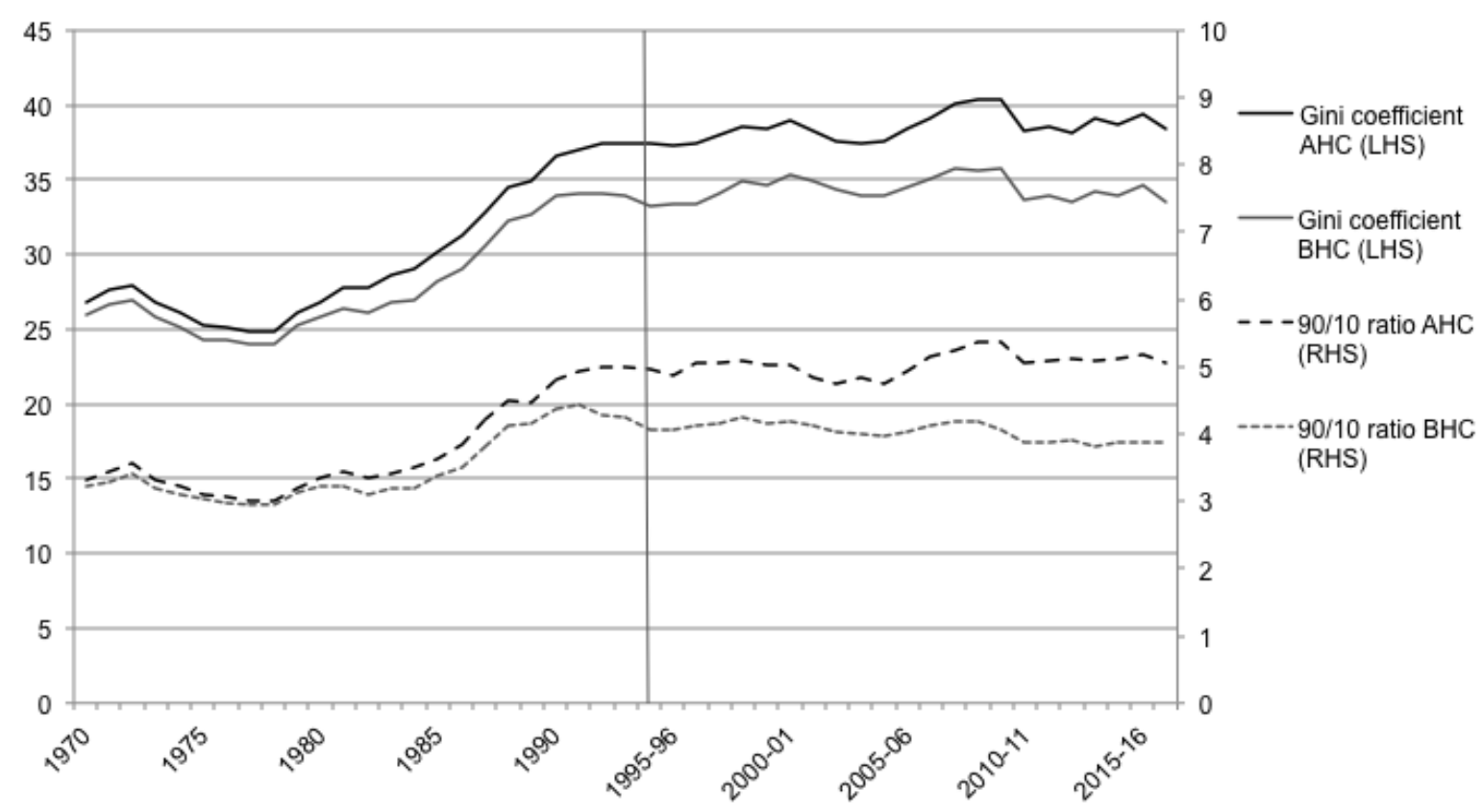

Source: IFS poverty and inequality spreadsheet (downloaded 28 January 2019). Gini coefficients and 90:10 ratios are for equivalised disposable incomes in Great Britain up to 2001-02 and UK thereafter. Data from FES until 1993 and FRS thereafter. See DWP (2018) for definitions and detailed results.

Note: This analysis covers all individuals, including children. Our analysis in later sections is for adults, excluding children.

In this article we focus on the twenty years after 1995-96. The overall trends for this period are far less dramatic than the recent rise in the salience of inequality might suggest. The 90:10 ratio, whether before or after housing costs, ended in 2016-17 close to where it started in 1995-96 - slightly up after allowing for housing costs, slightly down before allowing for them. Neither shows a dramatic rise after the crisis; if anything, there is a fall. The Gini coefficients reach high points around the time of the crisis, falling back sharply by 2010-11, with a rise afterwards that is reversed in the final year. As a general description, inequality has plateaued, rather than its increase continuing or reversing.

Other forms of UK economic inequality show contrasting trends. For instance, inequality in male hourly wages continued to grow between 1994 and 2014, with the 90:10 ratio rising from 4.1 to 4.5 (Belfield et al., 2017, using FRS data). However, this was much slower inequality growth than in the preceding twenty years. ${ }^{4}$

Wages are only one component of household income. One reason why income inequality narrowed immediately after the crisis was that policy at that stage continued to maintain the real value of the most important social security benefits. With real wages falling for those in work, generally higher up the income distribution than those for whom benefits are most important, this compressed some inequalities. The largest cuts in the real value of

\footnotetext{
${ }^{4}$ See Machin (2011), figure 11.1 for trends in 90:10 ratios of weekly earnings for men and women. The most rapid increases in these series were from 1980 to 1998, with a flattening of earnings inequality growth for women from 2000, but continued growth for men until 2005.
} 
benefits came later in the life of the Coalition and under the current Conservative government..$^{5}$

More generally, changes in the overall structure of direct taxes and benefits affect the relationship between market incomes (earnings and investment income) and disposable incomes (after state benefits and direct taxes). Analysis of a separate survey by the Office for National Statistics confirms that the big increases in both market ('original') and disposable income inequality occurred between 1979 and the early 1990s (ONS, 2019, table 11). Market income inequality in this series peaked in 1993. It fluctuated between the start of our period, 1995-96, and 2012-13 but then fell. As a result, the Gini coefficient for household market income was 1.7 percentage points lower in 2015-16 than in 1995-96 (falling to 46.6 per cent). Disposable income inequality also fluctuated between 1995-96 and 2005-06, dipping in the final year, giving a slightly smaller twenty-year fall of 1.1 percentage points. Redistribution through direct taxes and benefits did a little less to moderate inequality at the end than at the start. These trends are again less dramatic than some might expect, in both cases towards somewhat lower inequality in 2015 than in 1995.

Wealth inequalities also followed a distinct path. As Section 3 shows, household wealth inequality (as measured in the ONS Wealth and Assets Survey, WAS) increased slightly between 2006-08 and 2014-16, if private pension rights are included, but increased sharply, if they are excluded.

What has happened to overall economic inequalities in the UK in recent years therefore depends on the precise kinds of resources, time period, and parts of the distribution examined. This already suggests that developments below the surface may not have been uniform. In this article we present new analysis of data from a variety of sources to examine how inequalities changed both between and within population groups defined in different ways, including by characteristics protected by equalities legislation. It builds on the approaches used by the National Equality Panel (Hills, et al., 2010), which used data for years immediately before the crisis, and subsequent analysis (Hills, et al., 2015). It extends the analysis to cover the two decades from 1995 to 2015, looking in particular at which groups emerged as winners and losers in each decade.

Section 2 sets out our methods and the data sources used. Section 3 describes the trends in overall inequality shown by these data, and the sharp contrasts between the two decades. Section 4 examines the most pervasive change, that younger adults lost ground to older ones. Section 5 examines what happened to the better- and less well-off within groups defined by family type, region, tenure, ethnicity and disability status to see which, if any, were 'left behind'. The final section concludes.

\section{SOURCES AND METHODS}

We use three main data sources chosen to allow disaggregation between and within population groups: ${ }^{6}$

\footnotetext{
${ }^{5}$ See Hills, De Agostini, and Sutherland (2016) for discussion of the policy changes and their effects.

${ }^{6}$ See Data References [at the end of the paper/ with on-line version] for a listing of the datasets used.
} 
(1) Quarterly Labour Force Survey (LFS) individual data from all working-age adults ${ }^{7}$ on their hourly wages, weekly earnings, highest educational qualifications and economic activity by characteristics from 1995 to 2015 (UK). ${ }^{8}$

(2) FRS individual data from all adult household members matched to household level total net equivalised household income (as in the Department for Work and Pensions Households Below Average Income, HBAI, dataset). We examine before and after housing costs incomes from 1995-96 to 2015-16 (GB to 2001-02; UK subsequently).

(3) ONS/ CASE analysis of the Wealth and Assets Survey (WAS) looking separately at: (a) 'financial and physical wealth' (net financial assets and possessions excluding property such as housing); (b) net financial, physical and property wealth ('total nonpension wealth', also including property such as housing net of mortgages); and (c) total wealth including the value of private and occupational pension rights. We examine these by household characteristics for the two-year periods (starting in July) 2006-2008 to 2014-2016 (GB).

With ten potential classifications of population groups examined over a period of twenty years ${ }^{9}$, we can only be selective in what we present here. We also concentrate on three of the outcomes covered by our wider analysis ${ }^{10}$, chosen to capture some of the most important components of economic resources:

- Hourly wages for men and women working full-time (at 2015 prices, adjusted using the Consumer Price Index including owner-occupiers' housing costs and Council Tax, CPIH). ${ }^{11}$

- Equivalised household income after housing costs allocated to each adult in the population (at 2015-16 prices, adjusted using by DWP's bespoke variants of CPI, which exclude rents, maintenance repairs and water charges for AHC analysis). Where relevant, we refer to changes before allowing for housing costs.

- Total non-pension wealth (in nominal terms, not adjusted for inflation).

We concentrate on inequality within each group measured by changes at the tenth, fiftieth (median) and ninetieth percentiles for each group, and the 90:10 ratio between the first and last of these. For the wage and income data we contrast changes over equal length ten-year periods, the upswing period from 1995 to 2005 and the decade incorporating the

\footnotetext{
${ }^{7}$ We take 'working age' as 16 to State Pension Age. This was 16-59 for men throughout. For women SPA started rising from 2010. We include women aged under 60 up to 2011, under 61 in 2012 and 2013, and under 62 in 2014 and 2015. In line with ONS, we do not, however, adjust for the rise in the education 'participation age' from 16 to 17 in 2013.

${ }^{8}$ For some purposes, data from the Annual Survey of Hours and Earnings (ASHE) would be preferable to LFS data, but ASHE only allows limited breakdowns by characteristic. WAS data are likely to under-record the highest wealth-holders, but other sources do not permit the breakdowns possible from WAS. We use data from all four quarters of the LFS for each year. LFS interviews households for five consecutive quarters, so that each quarter one fifth of the sample is interviewed for the first time, one fifth for the second time, and so on. To avoid double-counting, we include only those interviewed for the first and fifth time (waves 1 and 5). These are the only waves that contain information on wages.

${ }^{9}$ In the full analysis we look at breakdowns by gender, age, ethnicity, religious affiliation, region, family status, housing tenure, disability status, country of birth. This analysis will be available in a series of papers and data tables on the CASE website: http://sticerd.lse.ac.uk/case/.

${ }^{10}$ In earlier analysis we also examined educational qualifications, employment status, weekly earnings, and individual (as opposed to household) incomes (Hills, et al., 2010; Hills, et al., 2015).

${ }^{11}$ ONS currently only publishes CPIH series back to 2005. We use estimated values of CPIH back to 1995 , kindly supplied by the Resolution Foundation.
} 
2008 economic crisis from 2005 to 2015. The WAS data start in 2006-2008 and so changes in them are only available for eight years within the second decade.

\section{OVERALL TRENDS IN UK INEQUALITY SINCE 1995}

Hourly wages

As a benchmark for the subsequent detailed analysis, this section looks at overall trends in the three outcomes. In the first decade, median pay grew by 20 per cent for men and nearly 30 per cent for women (Figure 2). ${ }^{12}$ Over the second decade, real pay fell at the tenth percentile for both men and women (but more for men), and at the median for men. At the ninetieth percentile there was limited pay growth for men and women comparing 2015 with 2005. As a result, women's pay inequality remained roughly stable over the entire period, but increased for men, despite the slight narrowing for both genders in the first decade. The greater rise in women's wages than men's meant that the gender wage gap narrowed across the distribution (although less at the top). This also meant that overall pay inequality for men and women together ended the same in 2015 it had been in 1995 (Table 2). But the dominant feature in these figures is the contrast between the two decades, with healthy growth in real pay in the first, but stagnation in the second.

\section{Figure 2: Percentage change in full-time hourly pay by gender, 1995 to 2015 (adjusted by CPIH)}

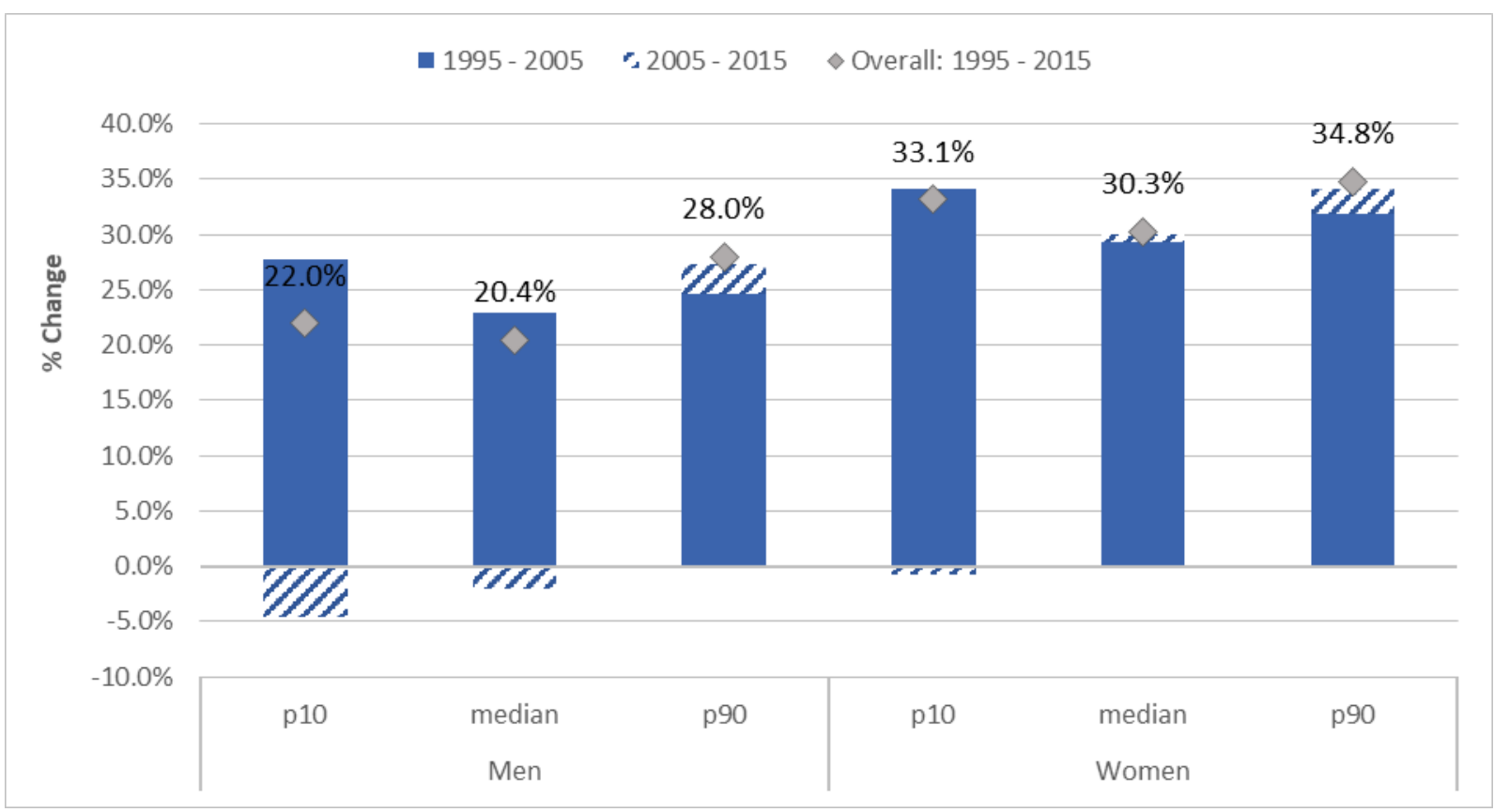

Source: Authors' analysis of LFS.

\section{Household incomes}

Figure 3 shows household income changes across the distribution over the two decades, measured both before housing costs in the upper panel, and after allowing for them in the lower panel. We include changes at $30^{\text {th }}$ and $70^{\text {th }}$ percentiles to give a little more detail.

\footnotetext{
${ }^{12}$ In these diagrams the solid part of the bar shows change in the first decade, and the hatched bar change in the second decade. The diamonds show the compounded 20 -year change.
} 
First, median household incomes before allowing for housing costs (BHC) grew by 39 per cent, more quickly than hourly pay. Falling housing costs meant that median after housing costs (AHC) income grew even faster -45 per cent. Overall household incomes grew faster than hourly pay (or weekly earnings) because pensioner households are included here. As Section 4 shows, with rising private and state pensions, incomes of those aged over 64 grew much faster than working-age incomes (much of them from pay), particularly after allowing for housing costs (Figure 6).

At the bottom, BHC incomes grew faster than at the top (although the $30^{\text {th }}$ percentile grew fastest), so the 90:10 ratio fell slightly over the period (as seen in Figure 1). By contrast with the rest of the distribution, tenth percentile AHC incomes grew no faster than before allowing for housing costs, with no rise at all between 2005-06 and 2015-16. As a result, the 90:10 ratio for AHC income grew over both decades. But the dominant feature is how little overall living standards improved in the second decade compared to the first, rather than the inequality changes.

Figure 3: Percentage change in household income, 1995-96 to 2015-16 (2015-16 prices)

(a) Before housing costs

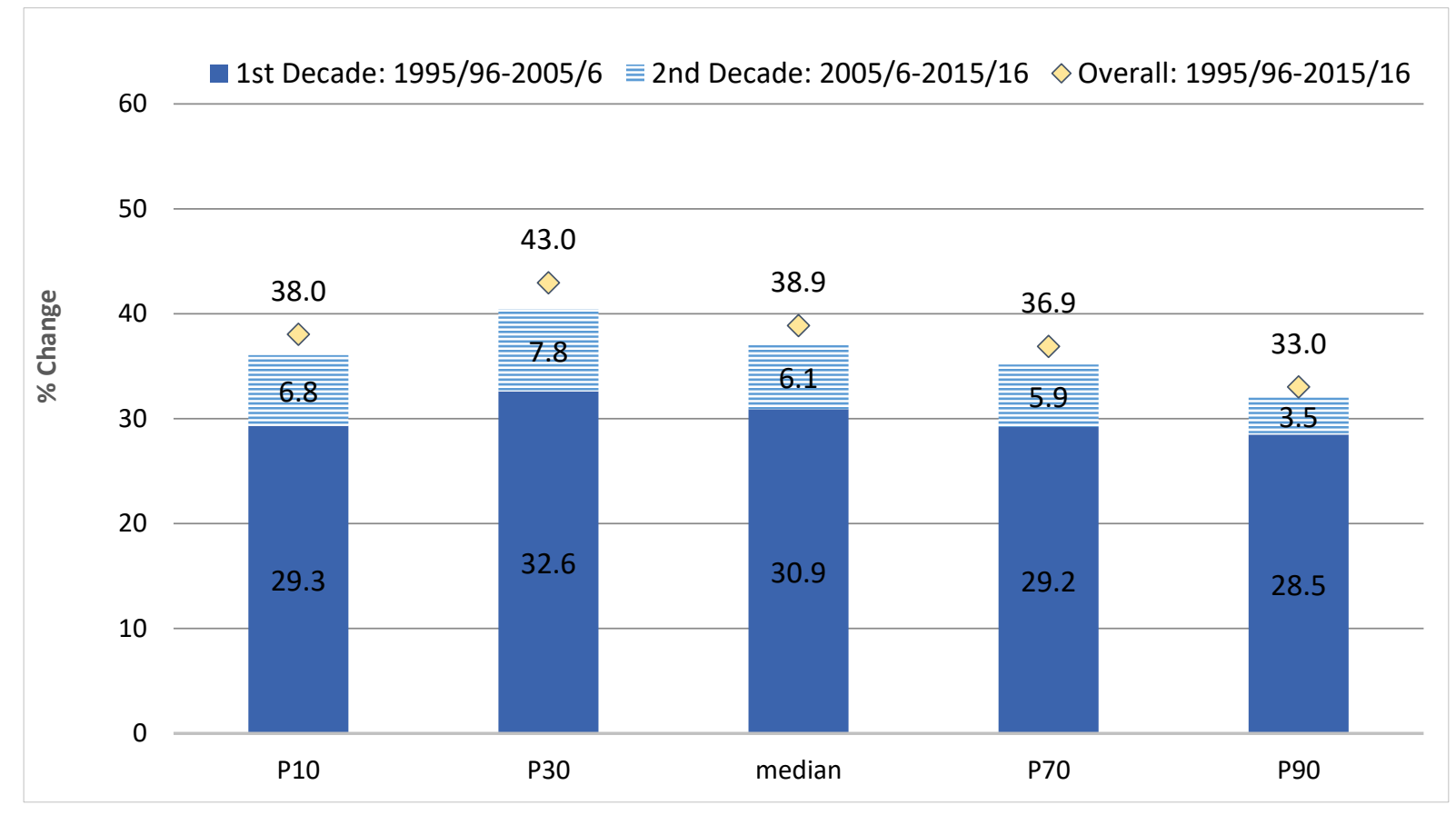


(b) After housing costs

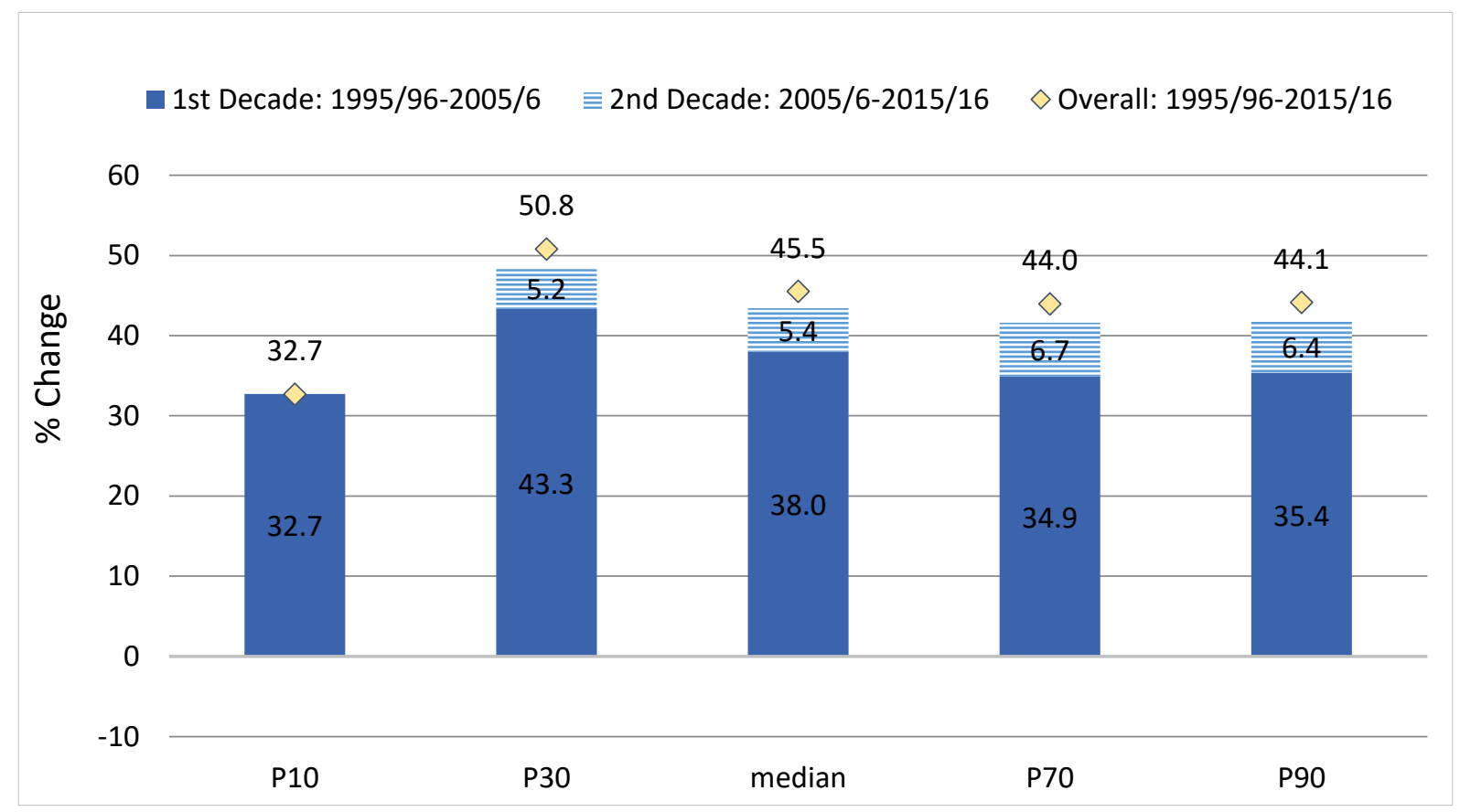

Source: Authors' analysis of FRS/HBAI.

Figure 4 shows levels of AHC income to which these changes correspond, year-byyear. This also emphasises the differences between the second and first decades, particularly at the tenth percentile, where income in 2015-16 was the same as in 2005-06, and shows how the precise years used to calculate changes can affect the picture. We use 2005-06 as the break-point in our analysis here to compare equal-length periods and to avoid over-emphasis on the peak. If instead, 2007-08 were used as the break-point, changes since then would look even more dismal for most. 
Figure 4: Levels of net household income (after housing costs) at different parts of the distribution, 1995-96 to 2015-16 ( $£$ /week, 2015-16 prices)

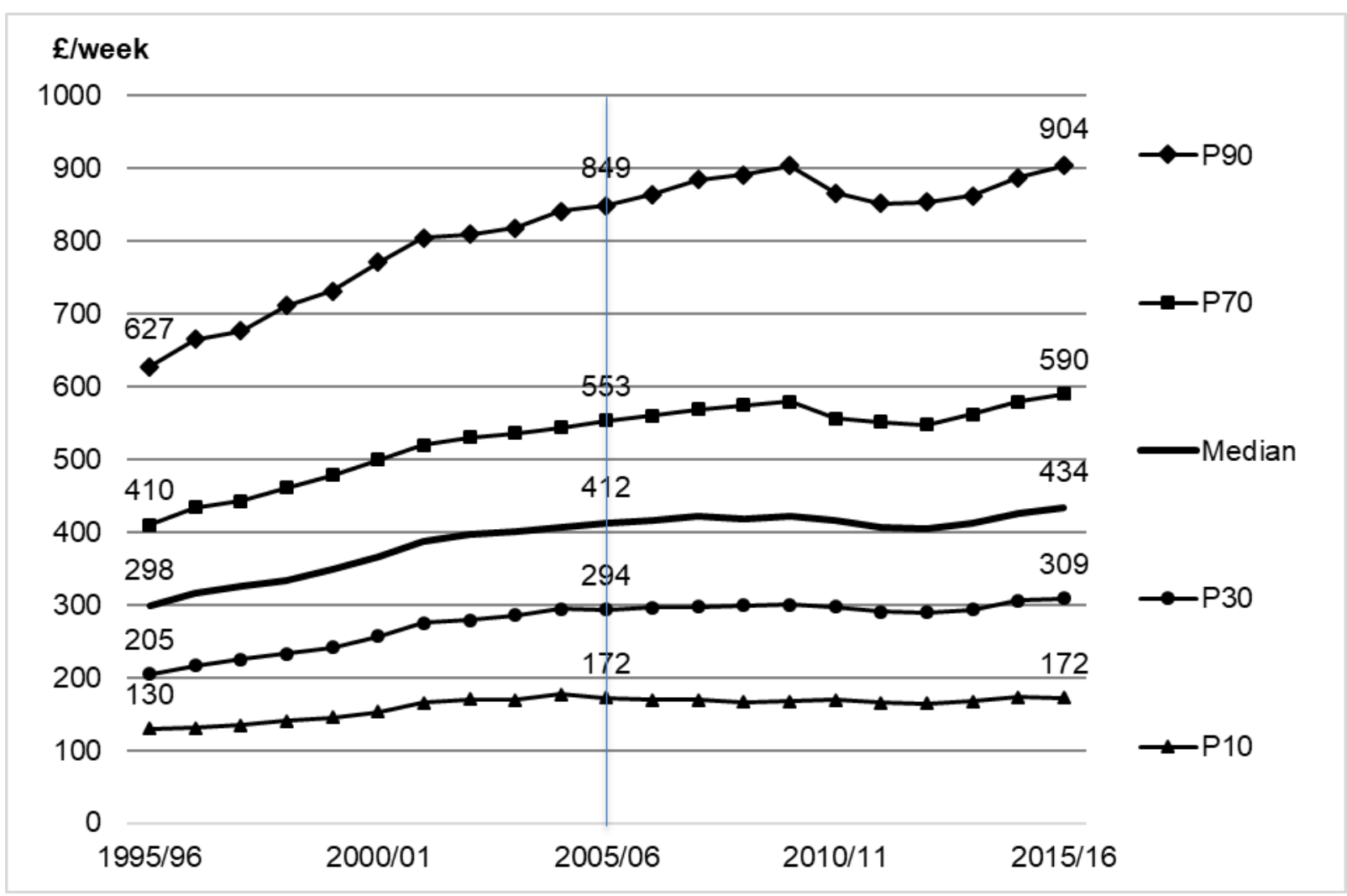

Notes: Incomes adjusted to equivalent for couple with no children.

Source: Authors' analysis of FRS/HBAI.

\section{Household wealth}

Nominal wealth totals grew over the eight years from 2006-08, contrasting with the slow growth in (real) wages and incomes. However, growth rates differed across the wealth distribution and for different types of wealth.

Growth in non-pension (physical, financial and property) wealth was much lower for those in the middle and at the bottom of the wealth distribution than at the top, resulting in increased inequality (Table 1). The 90:10 ratio for non-pension wealth grew from 65 in 200608 to 78 in 2014-16. This reflected lack of growth in (net) property wealth away from the top of the distribution. When ONS's estimates of the value of private pension wealth are added in, total wealth grew by 32 per cent at the median, but by 51 per cent at the tenth and 54 per cent at the ninetieth percentiles. The lower discount rates applied to promised future (defined benefit) pensions made their capitalized value much greater by the end of the period.

Given the huge differences in levels of wealth across the distribution, percentage changes convey only a little of what changed over time. For instance, the 51 per cent rise in total wealth at the tenth percentile was only worth $£ 4,600$, while 54 per cent at the ninetieth percentile meant a rise of $£ 424,000$, ninety times as much. For many purposes it is these absolute changes, and what they represent, for instance in their equivalent in years of average income, that will be most important. 
Table 1: Levels and changes in household wealth, 2006-08 and 2014-16 (nominal)

\begin{tabular}{|c|c|c|c|c|c|}
\hline & \multirow[b]{2}{*}{ Percentile } & \multirow[t]{2}{*}{ 2006-08 } & \multirow[t]{2}{*}{ 2014-16 } & \multicolumn{2}{|c|}{ Change 2006-08 to 2014-16 } \\
\hline & & & & 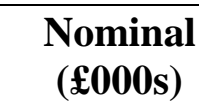 & Percentage \\
\hline \multirow{3}{*}{$\begin{array}{l}\text { Financial and } \\
\text { physical wealth }\end{array}$} & 10 & 6.0 & 7.4 & 1.4 & 23.3 \\
\hline & Median & 42.9 & 50.4 & 7.5 & 17.5 \\
\hline & 90 & 178.0 & 228.5 & 50.5 & 28.4 \\
\hline \multirow{3}{*}{$\begin{array}{c}\text { Financial, } \\
\text { physical, and } \\
\text { property } \\
\text { wealth }\end{array}$} & 10 & 7.5 & 8.1 & 0.6 & 8.0 \\
\hline & Median & 146.6 & 156.0 & 9.4 & 6.4 \\
\hline & 90 & 491.7 & 633.0 & 141.3 & 28.7 \\
\hline \multirow{3}{*}{$\begin{array}{c}\text { Total wealth } \\
\text { (including } \\
\text { pensions) }\end{array}$} & 10 & 9.0 & 13.6 & 4.6 & 51.1 \\
\hline & Median & 196.7 & 259.4 & 62.7 & 31.9 \\
\hline & 90 & 786.3 & $1,210.0$ & 423.7 & 53.9 \\
\hline
\end{tabular}

Source: ONS/CASE analysis of WAS.

The WAS data therefore suggest that total wealth inequality (including private pension rights) across the bulk of the household wealth distribution, as measured by the 90:10 ratio, increased very slightly between 2006-08 and 2014-16. The Gini coefficient, taking account of the top and bottom, also changed little, rising from 61 per cent to 62 per cent (ONS, 2018, table 4). However, non-pension wealth became more clearly unequal, with the 90:10 ratio rising from 66 to 78 . Gini coefficients for the property wealth and financial wealth components of non-pension wealth rose sharply, so the Gini coefficient for total wealth inequality excluding pensions increased from 59 to 63 per cent.

While the WAS data are very useful for the kinds of breakdown explored below, they are limited in coverage of the very wealthiest. Analyses that take account of other kinds of wealth data, including from estates, but also from newspaper data on the assets of the wealthiest, show greater inequality. Alvaredo, Atkinson and Morelli (2015, figures 2 and 3) show that data of those kinds suggest significantly greater shares of the total for the top 1 per cent and top 10 per cent than the WAS data, with increases in them since the early 2000 s.

In the detailed analysis below for space reasons and simplicity we concentrate on household wealth including financial assets and property but excluding estimated private pension rights. It should be remembered that overall inequality in this measure increased over the period, whereas it did not if pension rights were included.

\section{Summary}

This section emphasises two things: first, quite how good overall growth in real wages and incomes in the decade from 1995 look retrospectively compared to the dismal picture for the decade from 2005; and second that, in several respects, changes in overall inequality were small. Table 2 summarises this and gives benchmarks for later sections. Over the whole twenty years, hourly wage inequality was unchanged, incomes before housing costs became 
slightly less unequal, but incomes after housing costs more unequal. Over the second decade household wealth became more unequal when pension wealth is excluded.

Table 2: Overall inequality measured by 90:10 ratios, 1995-96, 2005-06 and 2015-16

\begin{tabular}{lccc}
\hline & $\mathbf{1 9 9 5 - 9 6}$ & $\mathbf{2 0 0 5 - 0 6}$ & $\mathbf{2 0 1 5 - 1 6}$ \\
\hline Hourly wages (1) & 3.8 & 3.7 & 3.8 \\
Income BHC (2) & 4.1 & 4.1 & 4.0 \\
Income AHC (2) & 4.8 & 4.9 & 5.3 \\
Total non-pension wealth (3) & na & 66 & 78 \\
Total wealth including pension & & & \\
wealth (3) & na & 61 & 62 \\
\hline
\end{tabular}

Sources: Authors' analysis of LFS and FRS/HBAI; ONS personal communication (total non-pension wealth); ONS (2018, table 4, for total wealth including pension rights).

Notes: (1) Hourly wages for full-time employees. (2) Total net equivalised household income for adults. The ratios are for GB up to 2001-02 and UK thereafter. These results differ slightly from Figure 1 as that relates to all individuals, while these relate to adults only, as used in following sections.

(3) Total non-pension wealth is financial, physical and property wealth of households. The associated years for data collection for wealth are 2006-08 and 2014-16.

\section{THE STEEPENING AGE GRADIENT}

The aggregate statistics presented above are often the focus of discussion, but disguise much that is going on beneath what appears a calm surface. Over the twenty-year period real wages grew across the overall distribution by at least a fifth, and real incomes after housing costs by at least a third. However, some groups gained much less or even lost, particularly after 2005. Similarly, while overall non-pension wealth grew across the wealth distribution after 2006-08, albeit much less in the middle and bottom half, it fell for some groups. This section reports on the pervasive differences we find by age. Section 5 focusses on those who have done particularly poorly when analysed by other characteristics.

While hourly wages increased for all age groups in the first decade, there was a remarkable contrast over the second decade. ${ }^{13}$ Median hourly wages fell for men and women between 2005 and 2015 in the age groups up to 30-34, but continued to grow for men aged over 54 and women aged over 34 (Figure 5). More detailed analysis shows that the first decade saw faster growth for younger men and women at the bottom of the wage distributions (P10) than at the median for their age groups, but their real losses in the second decade were greater than at the median. For the best-paid men and women there was also a strong age-gradation over the whole twenty-year period: the $90^{\text {th }}$ percentile for men aged 2529 rose by only 8 per cent, and by 19 per cent for women, while the $90^{\text {th }}$ percentiles for those aged 55-59 grew by 43 per cent for men and 36 per cent for women.

\footnotetext{
${ }^{13}$ For detailed discussion of the longer-term drivers of this, see Intergenerational Commission (2018), chapter 2.
} 
Figure 5: Change in median hourly wages (full-time employees) by age group, 1995 to 2015 (2015 prices, CPIH-adjusted)

(a) Men

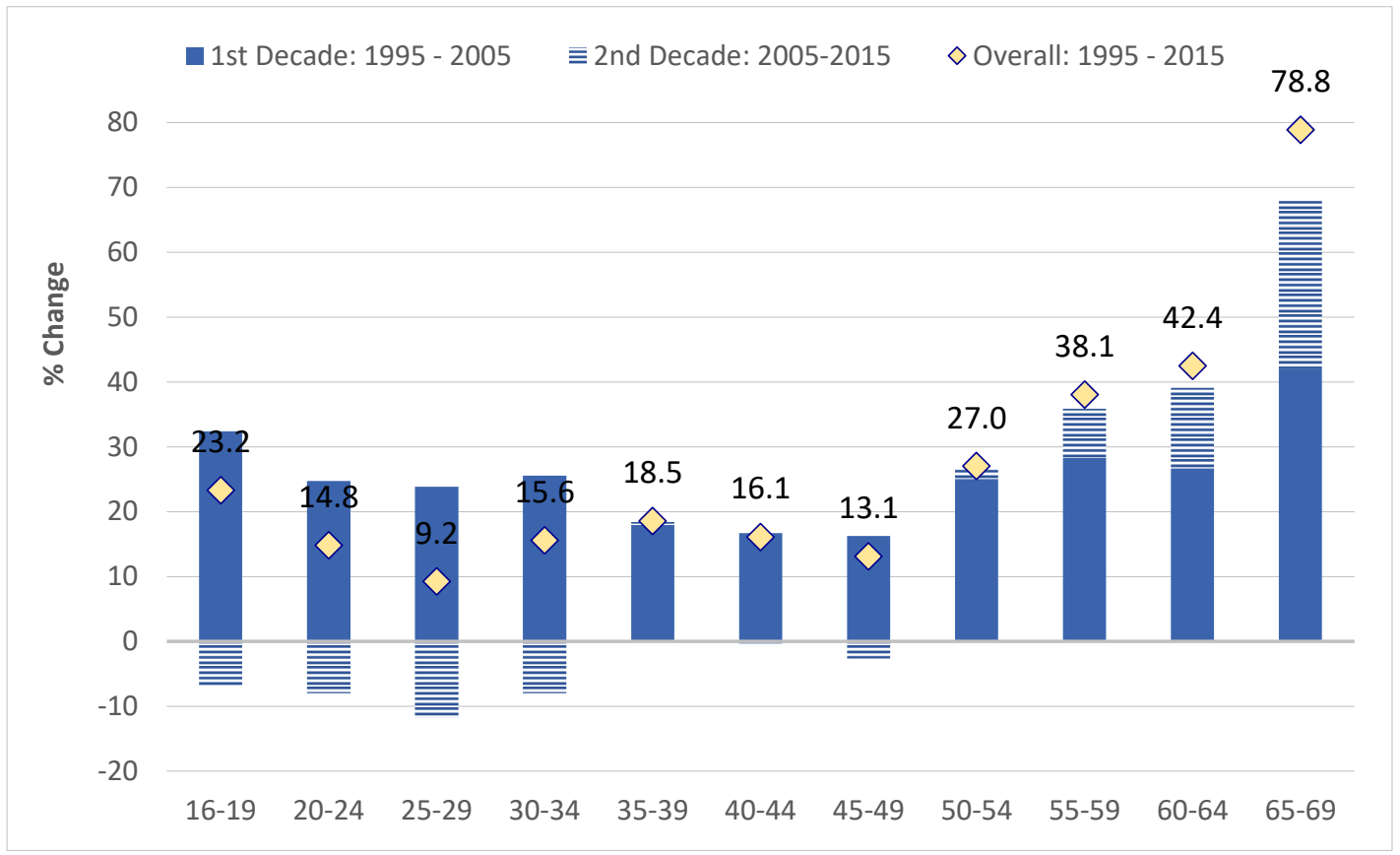

(b) Women

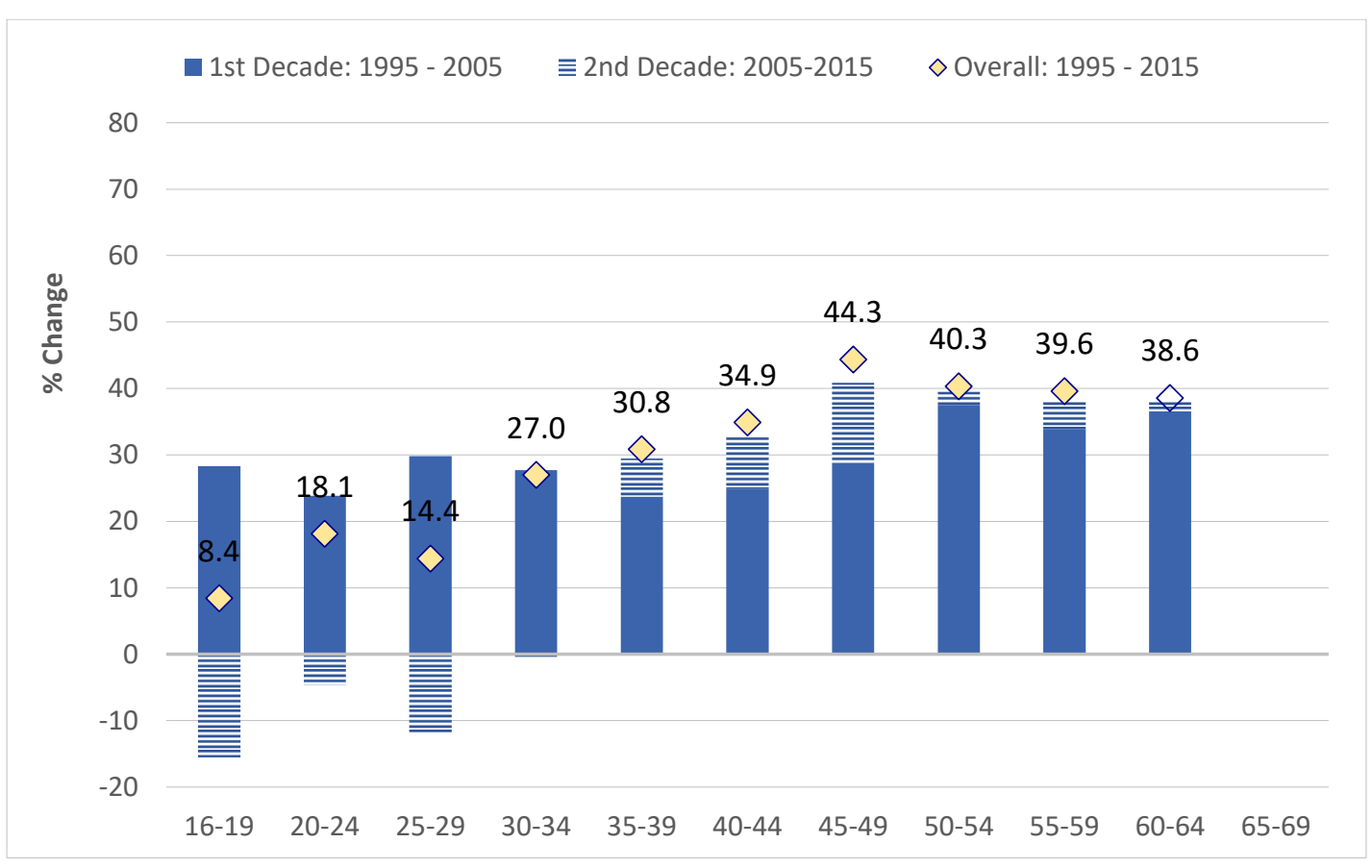

Source: Authors' analysis of LFS. Sample size for women aged 65-69 in 1995 too small for inclusion. 
This age gradation of economic fortunes is accentuated, looking at net incomes. Figure 6 shows that AHC incomes of those aged over $64{ }^{14}$ rose by more than 80 per cent over the whole period, including continued growth after 2005. But for those in their twenties, growth was less than 30 per cent, all of that occurring in the first decade. Those aged 80 or more gained a little less than younger pensioners, but still substantially.

Figure 6: Change in median incomes after housing costs by age group, 1995-96 to 201516 (2015-16 prices)

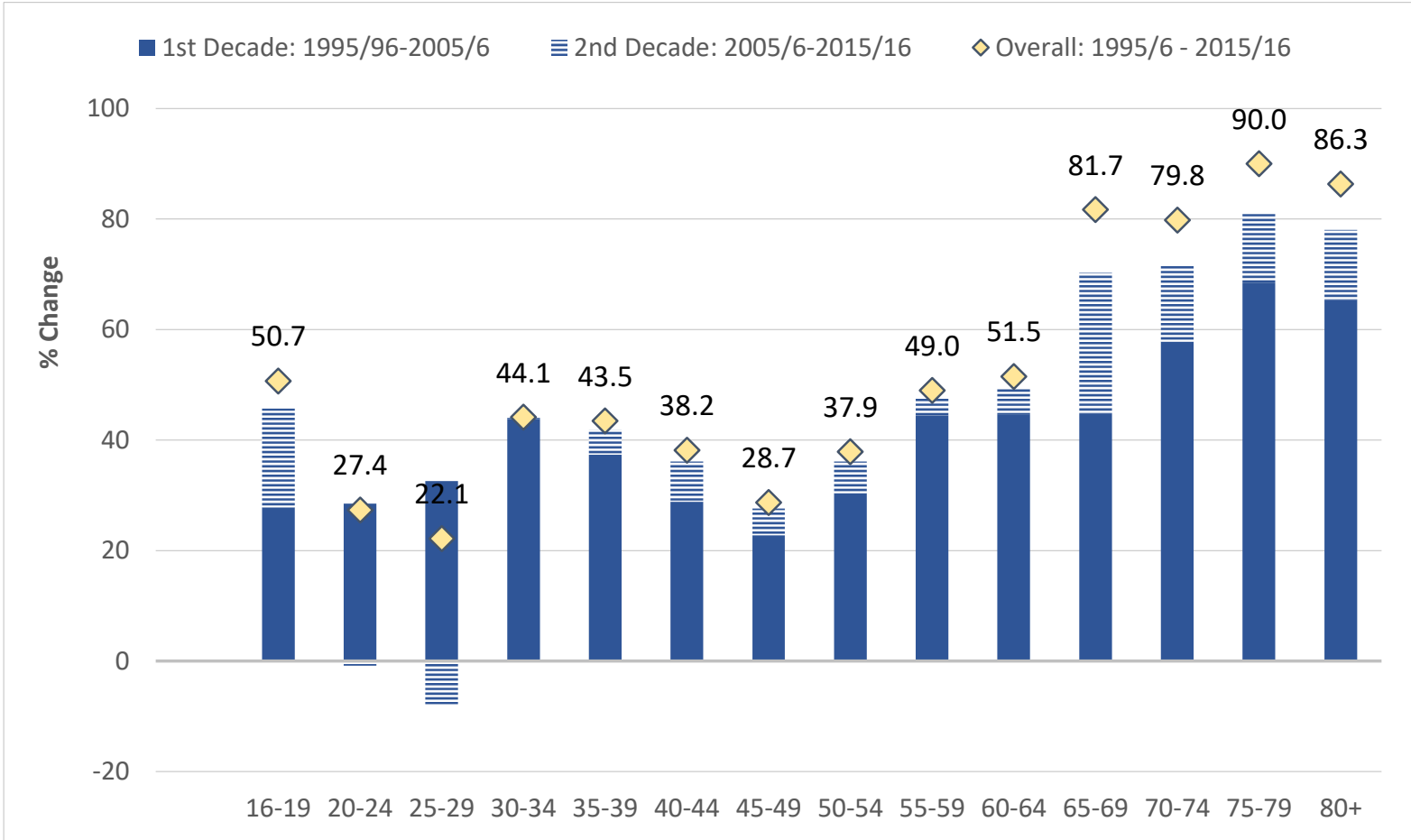

Source: Authors' analysis of FRS/ HBAI.

At the tops and bottoms of the distributions within each age group, income gains to those aged 65 and over were also much greater than for younger people, although there was less gradation by age within the working-age population than at the median. One striking exception was that incomes at the tenth percentile of those aged 60-64 were nearly 20 per cent lower in real terms in 2015-16 than for their equivalents in 2005-06. All of this fall occurred between 2010-11 and 2015-16. This coincided with the rise in women's State Pension Age, which meant that the social security safety net became much less generous for some in this age group. In addition, the tenth percentile for the group aged 80 or over fell by 3 per cent after $2005-06$, contrasting with 13 per cent growth for the poorest younger pensioners.

Changes in median non-pension wealth show an even more striking age difference: it fell by a sixth in nominal terms for the groups aged below 55, but grew by almost a third for those aged 65 or over (Table 3). Away from the medians, at the $90^{\text {th }}$ percentiles of the older groups, increases of 30 per cent or more represented substantial amounts - a 51 per cent rise meant wealth grew by $£ 300,000$ for the richest $65-74 \mathrm{~s}$. But even the $90^{\text {th }}$ percentile for 25 -

\footnotetext{
${ }^{14}$ In line with DWP's HBAI analysis, the distributions analysed here are for individual adults, based on the incomes of their households, so age groups are those of individuals.
} 
44 s grew by only $£ 5,000$, or 2.4 per cent. As a result, 55-64s now have median non-pension wealth $£ 216,000$ higher than those 30 years younger - equivalent to $£ 7,000$ for each year of age difference, even excluding accumulation of pension rights.

Table 3: Levels and changes in median household non-pension wealth, 2006-08 and 2014-16 by age group (nominal, £000s, GB)

$\begin{array}{lll}2006-08 & \text { 2014-16 } & \begin{array}{l}\text { Change 2006-08 to } \\ \text { 2014-16 }\end{array}\end{array}$

\begin{tabular}{lcccc} 
Age group & & & Nominal & Percentage \\
& & & & \\
\hline & & & & \\
$35-34$ & 47.6 & 39.6 & -8 & -16.8 \\
$45-54$ & 122.1 & 100.4 & -21.7 & -17.8 \\
$55-64$ & 185.6 & 152.4 & -33.2 & -17.9 \\
$65-74$ & 245.0 & 256.4 & 11.5 & 4.7 \\
$75-84$ & 214.5 & 283.5 & 69 & 32.2 \\
$85+$ & 184.1 & 242.4 & 58.3 & 31.7 \\
\hline
\end{tabular}

Source: ONS/CASE analysis of WAS. Age is that of household reference person.

Allowing for pension wealth makes the difference even larger. Median total wealth including pension wealth reached $£ 539,000$ for $55-64 \mathrm{~s}$ in $2014-16$, but was only $£ 67,000$ for $25-34$ s - almost $£ 16,000$ for each year of age difference. At the top, ONS's valuation of pension rights implies that a tenth of 55-64 year-old households had more than $£ 1.8$ million in total wealth, up by $£ 620,000$ from $2006-08$, and more than six times the $90^{\text {th }}$ percentile for $25-34$ s of $£ 310,000$.

\section{Summary}

In the second decade, the fortunes of younger adults declined sharply in all the respects we examine. Median hourly pay fell in real terms (CPIH adjusted) for men and women in the age groups up to 30-34 between 2005 and 2015. However, pay continued to grow for men aged over 54 and women aged over 34 . Over the whole twenty years, pay grew by more than a third for men and women aged 55 and over, but by less than 20 per cent for those in their twenties. Even for the best-paid men and women at each age there was a strong age-gradation in growth.

This carried over into more complete measures of income, with those over State Pension Age gaining most. After allowing for housing costs, median incomes of those aged 65 or over rose by more than 80 per cent over the whole period, including continued growth after 2005. But for those in their twenties, growth in median incomes was less than 30 per cent, all coming in the first decade. One notable exception was that, as women's State Pension Age rose, affecting the value of their state safety net, real incomes at the tenth percentile for those aged 60-64 were nearly 20 per cent lower in real terms in 2015-16 than for their equivalents in 2005-06. And incomes for the poorest over-80s fell after 2005-06, in contrast to the poorest younger pensioners. Already large wealth differences widened over 
the period: median non-pension wealth fell by a sixth in nominal terms for the groups aged below 55, but grew by almost a third for those aged 65 or over.

\section{WHO ELSE WAS 'LEFT BEHIND’ OVER TWO DECADES?}

Given space constraints, we present a very selective look at changing economic outcomes within and between groups defined in other ways, concentrating on those who fell behind in real terms or relative to other groups. It was often the already poorest within particular groups who fell furthest behind, even if the group as a whole fared reasonably well. We therefore concentrate in places on the tenth percentiles of some groups. We look in turn at family type, region or nation, housing tenure, ethnicity, and disability status.

\subsection{Family type}

The age gradation in economic fortunes described in Section 4 is reflected in differences between family types. Adults living in pensioner couple households and single pensioner adults saw the sharpest increases in their household incomes after housing costs across the distribution over the whole period from 1995-96 to 2015-16, with gains of 75 and 81 per cent at the median, respectively, including growth in the second decade. For lone parents there were sharp differences between the poorest and others. While median lone parent incomes after housing costs were a substantial 65 per cent higher in 2015-16 than in 1995-96, Figure 7 shows that modest growth at the tenth percentile for lone parents in the first decade was almost reversed in the second, leaving the overall real income growth of only 3 per cent over twenty years, well behind the poorest of other family types.

Figure 7: Change in incomes after housing costs at tenth percentile for each family type, 1995-96 to 2015-16 (2015-16 prices)

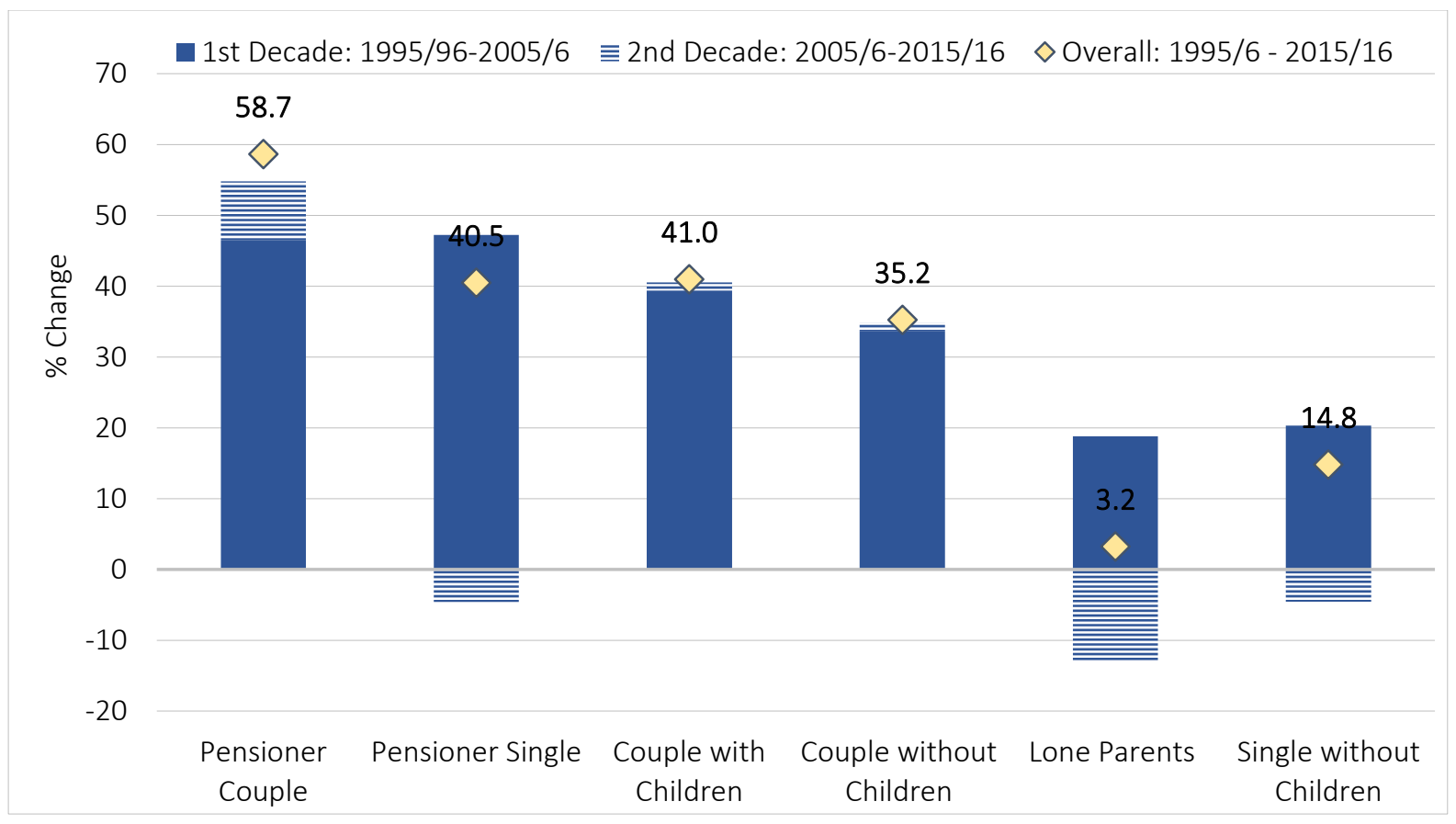

Source: Authors' analysis of FRS/HBAI. 


\subsection{Region}

National figures for hourly wage growth shown earlier also mask substantial differences between regions and nations. For men, the first decade showed variation, from 17 per cent median wage growth in the East Midlands to nearly 40 per cent in Northern Ireland. For women median wage growth was also fastest (35 per cent) in Northern Ireland as well as in the South West in the first decade, while it was slowest (23 per cent) in the South East. In the second decade median wages fell in most regions, with women in London worst hit (falling 6 per cent), but median women's wages in Scotland rising most, by 9 per cent. However, what happened to wages in London was generally unexceptional, in contrast to what we show below for incomes and wealth.

The upper panel of Figure 8 shows that BHC incomes rose fastest in London in the first decade (data were not available for Northern Ireland). Over the whole twenty years London's income growth was behind only the North East, which grew much faster than elsewhere after 2005-06.

The lower panel shows how much faster median AHC incomes rose by than hourly pay or BHC incomes - by nearly two-thirds over the twenty years in the North East and more than half in the South West. But London's position changes dramatically, becoming one of the four slowest growth regions.

Rather little correspondence emerges here between regions that lagged in household income terms, and those that are often perceived as having been 'left behind'. It is at a subregional scale that the contrasts between, for instance, cities such as Manchester and their surrounding towns emerge (Beatty and Fothergill, 2016).

Figure 8: Change in median incomes by region, 1995-96 to 2015-16 (2015-16 prices)

\section{(a) Before housing costs}

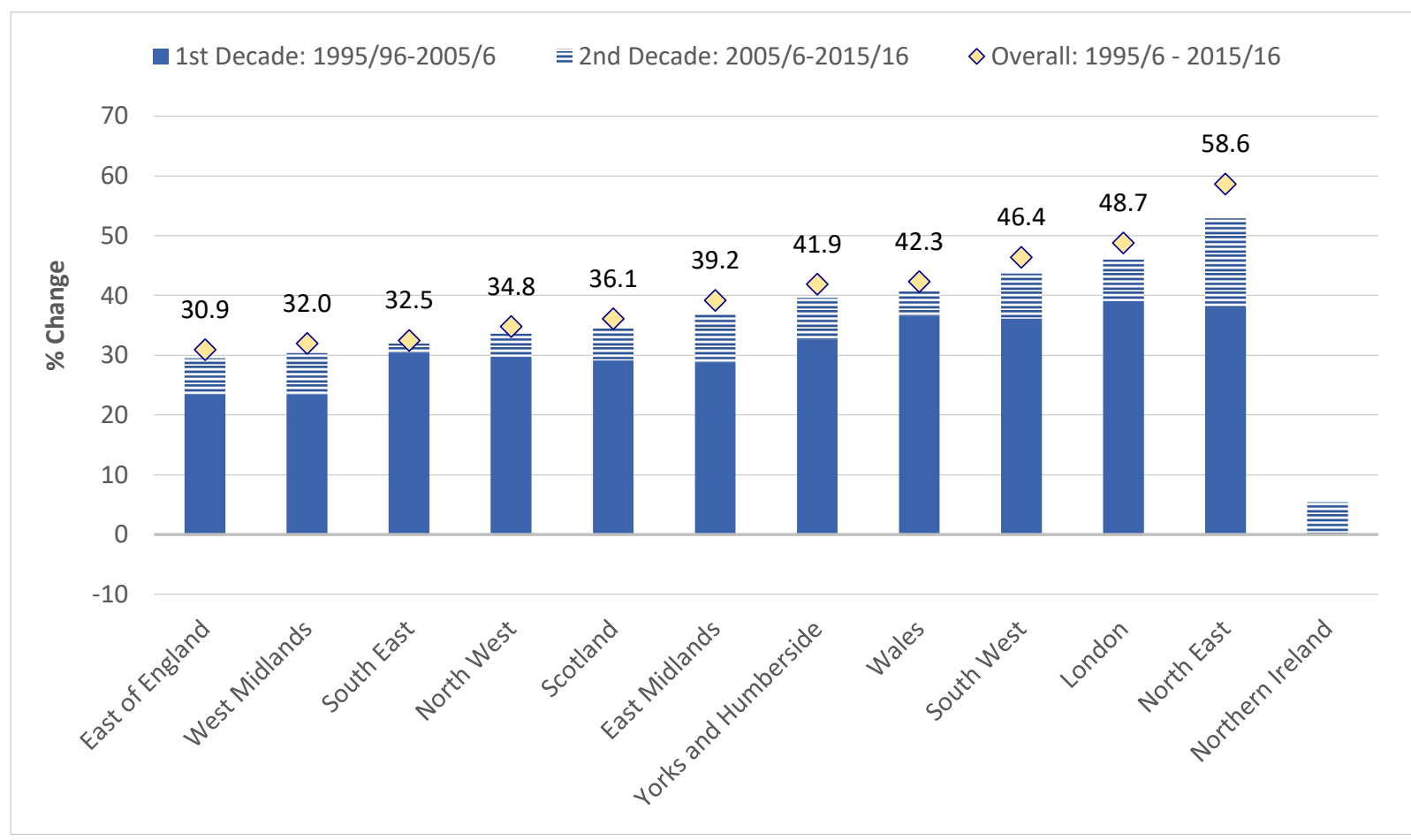


(b) After housing costs

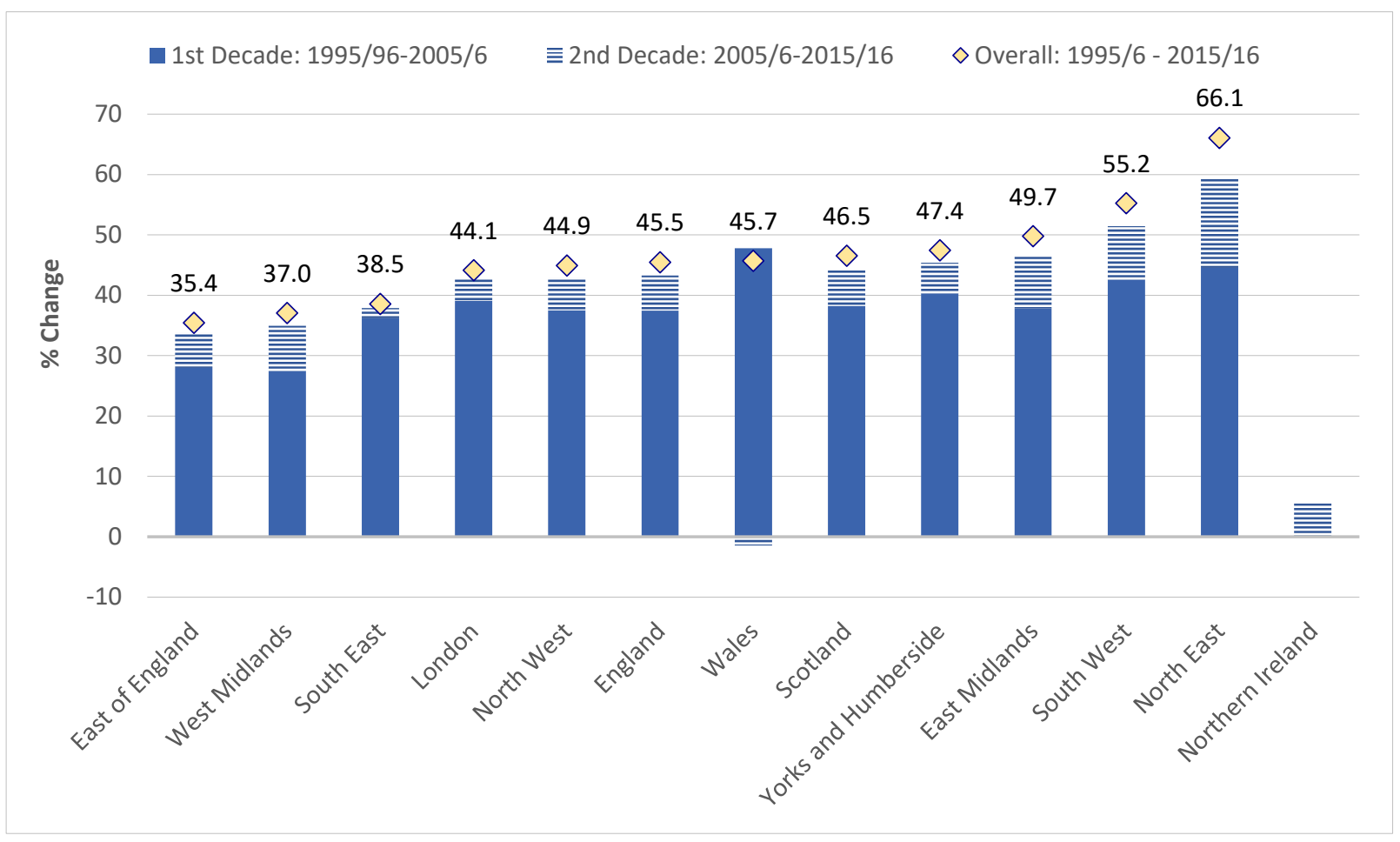

Source: Authors' analysis of FRS/HBAI.

Note: FRS figures are for GB only up to 2001-02, so change in first decade unavailable for NI.

But the differences are starker away from median regional incomes after allowing for housing costs. At the bottom (tenth percentile), Londoners' incomes grew by 28 per cent in the first decade, but fell by 14 per cent in the second decade, meaning they only rose 10 per cent over the whole twenty years. Figure 9 shows the levels of the tenth percentiles for selected regions that were below the tenth percentile for England as a whole in either 1995-95 or 2015-16. In 1995-96 the poorest Londoners were only slightly below the next poorest (in the North East). By 2015-16, the tenth percentile for Londoners had fallen to only 72 per cent of the poorest in the East Midlands (now the next lowest). The poorest Londoners lagged behind because of their rising housing costs: before housing costs, incomes for the poorest Londoners grew more than in most other regions. 
Figure 9: Income after housing costs at the $10^{\text {th }}$ percentile for selected regions $(£ / w e e k$, 2015-16 prices)

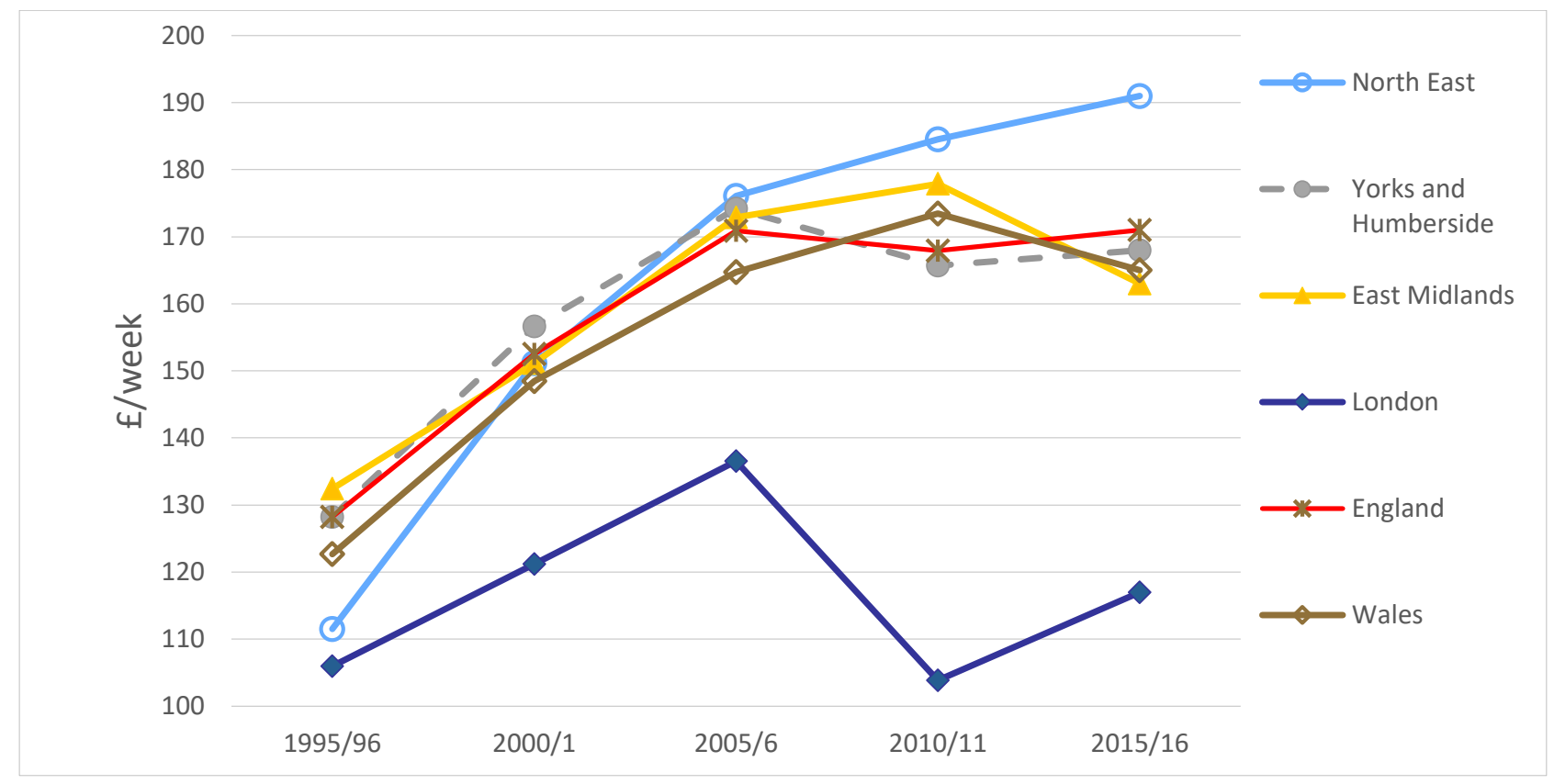

Source: Authors' analysis of FRS/HBAI.

Note: FRS figures are for GB only up to 2001-02.

Even at the ninetieth percentile, Londoners' AHC incomes fell after 2005, so despite having largest growth in the first decade, the overall growth for the highest-income Londoners (41 per cent over 20 years) was a little less than growth at the ninetieth percentile nationally. The decline in AHC income after 2005-06 for the poorest Londoners meant that inequality in London measured by the 90:10 ratio - already 7 in 1995-96, compared to 4-5 in most other regions - was over 9 in 2015-16, compared to less than 6 in any other region The poorest tenth of Londoners had less than $£ 120$ per week in 2015-16, while the richest tenth of Londoners had more than $£ 1,080$ per week.

Wealth inequalities between London and other regions and within London are even more dramatic (Table 3). Median non-pension wealth of London households grew by 87 per cent (over $£ 100,000$ ) in eight years within the second decade when wages and incomes rose so sluggishly. In several regions median nominal wealth fell. Median wealth in London and the North East were similar in 2006-08, but by the end median Londoners were $£ 130,000$ wealthier. While wealth grew by 88 per cent at the $90^{\text {th }}$ percentile in London, it only rose by 14 per cent at the $10^{\text {th }}$ percentile, so the $90: 10$ ratio in the capital reached an extraordinary 330 in 2014-16, far higher than elsewhere, where it varied between 50 and 80. 
Table 3: Levels and changes in median household non-pension wealth by region, 200608 and 2014-16 (nominal, £000s, GB)

\begin{tabular}{lcccc} 
& $\begin{array}{c}\text { 2006- } \\
\text { 08 }\end{array}$ & 2014-16 & \multicolumn{2}{c}{ Change 2006-08 to 2014-16 } \\
\cline { 2 - 5 } & & & Nominal & Percentage \\
& & & & \\
\hline Great Britain & 147 & 156 & 9.4 & 6.4 \\
England & 152 & 163 & 10.3 & 6.8 \\
East Midlands & 154 & 128 & -25.8 & -16.8 \\
East & 183 & 193 & 10.2 & 5.6 \\
London & 119 & 224 & 104.4 & 87.4 \\
North East & 117 & 85 & -31.3 & -26.8 \\
North West & 118 & 128 & 10.1 & 8.6 \\
South East & 209 & 240 & 31.1 & 14.9 \\
South West & 194 & 203 & 9.1 & 4.7 \\
West Midlands & 142 & 132 & -10.0 & -7.0 \\
Yorks \& Humber & 125 & 125 & 0.3 & 0.2 \\
Scotland & 107 & 123 & 16.4 & 15.3 \\
Wales & 143 & 128 & -14.8 & -10.4 \\
\hline Source: ONS/CASE & & & & \\
\hline
\end{tabular}

Source: ONS/CASE analysis of WAS.

\subsection{Tenure}

The composition of housing tenures changed considerably over the period, with access to both social housing and owner-occupation becoming more difficult for those in their twenties and thirties, more of whom therefore became private tenants (Intergenerational Commission, 2018, chapter 3). As a result, comparisons across tenures in 2015 and 1995 do not necessarily compare like-with-like, so need careful interpretation. For hourly wages, the main contrast was between owners with faster wage growth and tenants with slower growth (for both men and women). The exception was the lowest-paid social tenants, whose hourly wages rose by 32 per cent over twenty years for men and 35 per cent for women, following introduction of the National Minimum Wage in 1999. Real wages grew by nearly half for the best-paid male outright owners.

Figure 10 shows that apart from social tenants at the tenth percentile (whose incomes fell after 2005) and private tenants at the ninetieth percentile (whose incomes were flat), there were increases in AHC incomes across the distributions by tenure. Incomes rose by more than 45 per cent overall for each of the owner-occupier groups shown (more than 60 per cent for poorer outright owners). By contrast incomes after housing costs fell by 8 per cent for the poorest social tenants in the second decade. This meant that their incomes were only 5 per cent higher in 2015-16 than they had been 20 years before. 
Figure 10: Change in median incomes after housing costs by housing tenure, 1995-96 to 2015-16 (2015-16 prices)

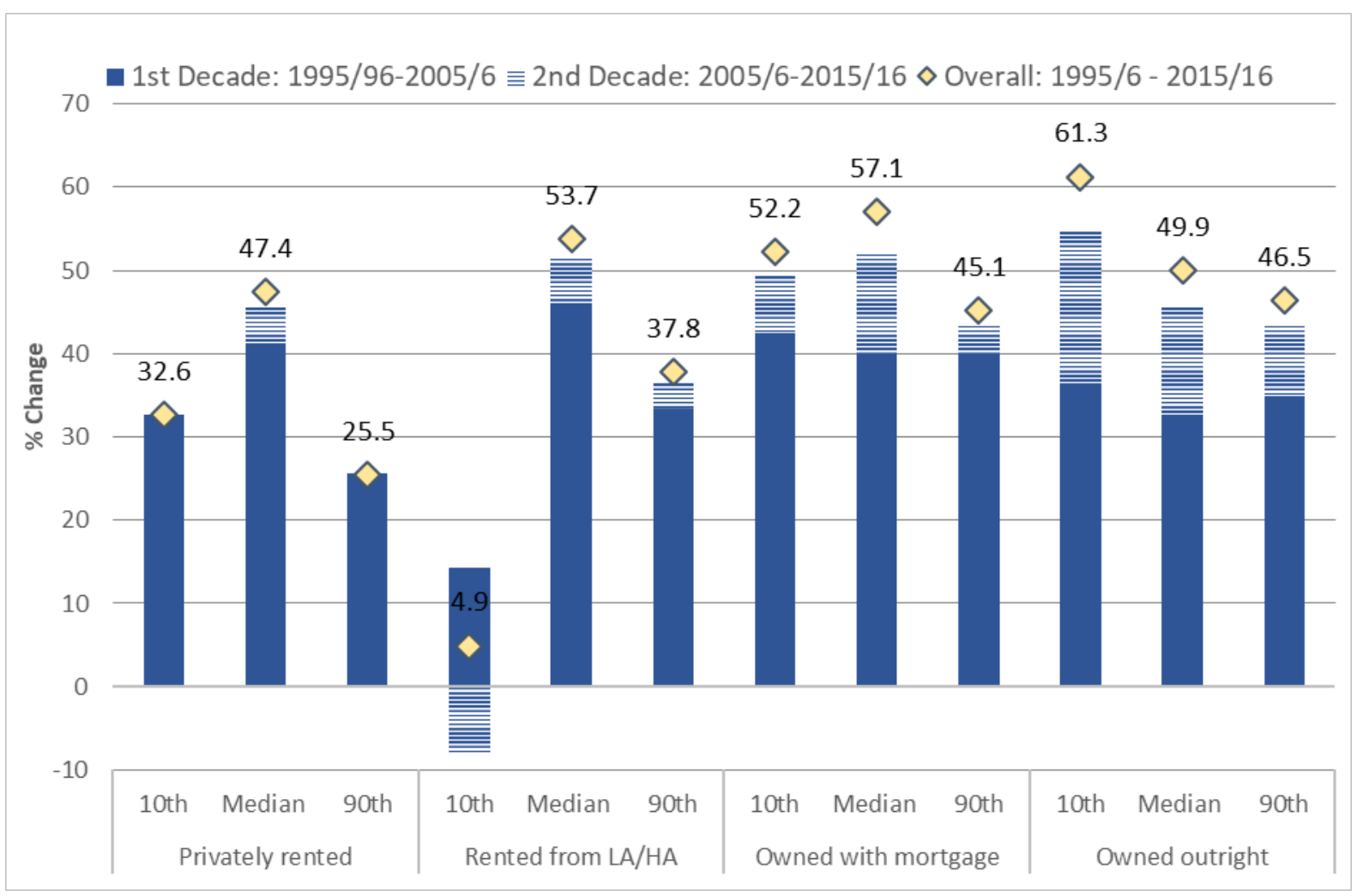

Source: Authors' analysis of FRS/HBAI.

The result is a stark difference between tenures in household income levels by 201516. Outright owners had median net weekly income AHC of $£ 556$, more than twice that of median social tenants with $£ 270$. At the top, a tenth of outright owners had weekly incomes over $£ 1,000$, while at the bottom a tenth of private tenants had incomes below $£ 100$, after their housing costs, and a tenth of social tenants under $£ 120$.

Since the total wealth measure we are using here includes property, it is not surprising that households that were outright owner-occupiers had the highest levels of non-pension wealth in both years and also the largest growth over the period across the distribution. Median non-pension wealth for outright owners increased by 26 per cent (or $£ 75,000$ ), while that for social and private tenants only by 8 per cent (or $£ 1,200)$ and 15 per cent (or $£ 2,500$ ), respectively. At the bottom of the wealth distribution patterns are even more varied: 14 per cent $(£ 19,000)$ growth in wealth for the outright owners, no change for social renters but a fall of a third $(£ 600)$ in the already low wealth of the poorest private renters. Faster growth in wealth at the top of the distribution for each tenure group - including by a third to $£ 965,000$ for the best-off outright owners - meant that inequality within tenures grew. The already high 90:10 ratio for wealth of private tenants grew from 51 to 83, while that for outright owners also grew, to 6.2. 
Table 4: Levels and changes in household non-pension wealth by housing tenure, 200608 and 2014-16 (nominal, £000s, GB)

\begin{tabular}{|c|c|c|c|c|c|}
\hline & \multirow[b]{2}{*}{ Tenure } & \multirow[t]{2}{*}{ 2006-08 } & \multirow[t]{2}{*}{ 2014-16 } & \multicolumn{2}{|c|}{$\begin{array}{l}\text { Change 2006-08 to } \\
2014-16\end{array}$} \\
\hline & & & & Nominal & Percentage \\
\hline \multirow{4}{*}{ P10 } & $\begin{array}{l}\text { Outright } \\
\text { owner }\end{array}$ & 135.5 & 154.5 & 19 & 14 \\
\hline & Mortgagor & 56.6 & 59.0 & 2.4 & 4.2 \\
\hline & Social tenant & 2.5 & 2.5 & 0 & 0 \\
\hline & $\begin{array}{l}\text { Private } \\
\text { tenant }\end{array}$ & 1.9 & 1.3 & -0.6 & -31.6 \\
\hline \multirow{4}{*}{ Median } & $\begin{array}{l}\text { Outright } \\
\text { owner }\end{array}$ & 285.8 & 360.9 & 75.1 & 26.3 \\
\hline & Mortgagor & 177.0 & 184.2 & 7.2 & 4.1 \\
\hline & Social tenant & 14.8 & 16.0 & 1.2 & 8.1 \\
\hline & $\begin{array}{l}\text { Private } \\
\text { tenant }\end{array}$ & 17.0 & 19.5 & 2.5 & 14.7 \\
\hline \multirow{4}{*}{ P90 } & $\begin{array}{l}\text { Outright } \\
\text { owner }\end{array}$ & 728.7 & 965.2 & 236.5 & 32.5 \\
\hline & Mortgagor & 481.8 & 569.6 & 87.8 & 18.2 \\
\hline & Social tenant & 50.4 & 54.8 & 4.4 & 8.7 \\
\hline & $\begin{array}{l}\text { Private } \\
\text { tenant }\end{array}$ & 97.2 & 107.6 & 10.4 & 10.7 \\
\hline
\end{tabular}

Source: ONS/CASE analysis of WAS.

\subsection{Ethnicity}

What we can present by ethnicity on a consistent basis is limited by data limitations, especially in the first decade. Table 5 therefore summarises what the sources show for the second decade. The patterns are not straightforward, however:

- For White respondents, male wages fell more than for all men, but women's wages and household incomes and wealth grew more than for all women.

- The wealth of Indian households grew more rapidly, with median wealth exceeding the overall median and that of the White ethnic group by 2014-16.

- Pakistani male wages and household income and wealth grew more rapidly than for the whole population, but female wages fell by more than 10 per cent.

- Bangladeshi incomes grew by a third over the period, even though male hourly wages fell by more than most other groups.

- For income and wealth Black Caribbean households had rapid growth, but by contrast Black African households became poorer. Wages fell for both men and women for the two groups combined. 
- Male wages and wealth grew rapidly for Chinese respondents, but household incomes fell.

The most notable difference is between those with Pakistani and Black African ethnicities, with the latter showing most signs of being 'left behind' after 2005.

Table 5: Changes in median hourly pay, after housing costs incomes and wealth by ethnicity, selected groups, 2005 to 2015

\begin{tabular}{|c|c|c|c|c|c|}
\hline & \multicolumn{2}{|c|}{ Hourly wages } & $\begin{array}{l}\text { Income } \\
\text { after } \\
\text { housing } \\
\text { costs }\end{array}$ & \multicolumn{2}{|c|}{$\begin{array}{l}\text { Median non-pension } \\
\text { wealth (nominal) }\end{array}$} \\
\hline & \multicolumn{2}{|c|}{$\begin{array}{c}\text { Per cent change } \\
2005 \text { to } 2015(2015 \\
\text { prices })\end{array}$} & \multirow{2}{*}{$\begin{array}{c}\text { Per cent } \\
\text { change } \\
2005-06 \\
\text { to } 2015- \\
16(2015- \\
16 \text { prices) }\end{array}$} & \multirow{2}{*}{$\begin{array}{l}\text { Per cent } \\
\text { change } \\
2006-08 \text { to } \\
2014-16\end{array}$} & \multirow{2}{*}{$\begin{array}{c}\text { Wealth } \\
\text { level } \\
\text { 2014-16 } \\
\text { (£000s) }\end{array}$} \\
\hline & Men & Women & & & \\
\hline All & -2.1 & 0.8 & 5.7 & 6.4 & 156.0 \\
\hline White & -2.6 & 1.4 & 6.5 & $6.7^{2}$ & $166.4^{2}$ \\
\hline Indian & 1.8 & 2.9 & 9.5 & 21 & 185.4 \\
\hline Pakistani & 13.7 & -11.3 & 20.2 & 30.2 & 113.4 \\
\hline Bangladeshi & -7.2 & $\mathrm{Na}^{3}$ & 33.0 & 5.3 & 15.8 \\
\hline Black Caribbean & $70^{3}$ & 60 & 23.0 & 23.2 & 46.8 \\
\hline Black African & $-1.9^{\circ}$ & -0.0 & -21.4 & -13.5 & 15.4 \\
\hline Chinese & 28.0 & 3.1 & -0.7 & 106.6 & 119.4 \\
\hline
\end{tabular}

Sources: Authors' analysis of LFS and FRS/HBAI; ONS/CASE analysis of WAS. Individual's own ethnicity in LFS and FRS and that of household reference person in WAS analysis.

Notes: 1. Income figures based on three years' pooled data centred in 2005-06 and 2015-16. 2. Wealth figures are for White British. 3. Sample size below 30 in one of the years. 4. Hourly pay is for 'Black African', 'Black Caribbean' and 'Black Other' combined. LFS and FRS figures are for the UK; WAS figures are for GB.

\subsection{Disability status}

Data limitations also restrict what we can present consistently across the first decade, so Table 6 concentrates on changes in the second decade in comparing groups by disability status (and as the table notes explain, available definitions vary between the surveys). Note that people reporting disability tend to be older than those who do not, so some of the raw results in Table 6 are also due to age differences, boosting the wealth of disabled households in particular. ${ }^{15}$ Remembering those caveats:

\footnotetext{
${ }^{15}$ See McKnight (2014). She shows, for instance, a 'disability penalty' of $£ 133,000$ for non-pension wealth for 45-54 year-olds in 2005, comparing those who were disabled five and ten years earlier with their peers who were not. This is much larger than the raw difference of $£ 30,000$ in 2005 shown in Table 6 for all ages.
} 
- In all the comparisons shown, disabled people and households had lower levels of pay, income and wealth. For instance, median AHC incomes of adults reporting a disability in 2015 were only 77 per cent of those who did not.

- Median hourly pay fell by 7 per cent for disabled women.

- By contrast median pay rose by 5 per cent for disabled men, while it fell slightly for non-disabled men. However, for the lowest-paid disabled men pay fell by 8 per cent, while it fell only slightly for the lowest-paid other men.

- While median incomes rose at the same rate for disabled and non-disabled individuals, incomes for the poorest disabled household fell by 7 per cent.

- Despite the more rapid growth in wealth for older households shown in Section 4, the median non-pension wealth of disabled households fell in nominal terms by 7 per cent between 2006-08 and 2014-16, while median wealth grew 12 per cent for nondisabled ones.

In most respects, therefore, disabled individuals and households lost ground between 2005 and 2015, particularly those with the lowest incomes.

Table 6: Levels and changes in median and tenth percentile hourly wages, AHC incomes, and wealth by disability status, 2005 to 2015

\begin{tabular}{|c|c|c|c|c|c|c|}
\hline & Not dis & & & sabled & & \\
\hline & 2005 & 2015 & \% change & 2005 & 2015 & $\begin{array}{c}\% \\
\text { change }\end{array}$ \\
\hline Median & ses $(£, 2$ & prices) & & & & \\
\hline Men & 12.9 & 12.6 & -2 & 10.9 & 11.5 & 5 \\
\hline Women & 11.2 & 11.3 & 1 & 10.3 & 9.6 & -7 \\
\hline Tenth p & urly wa & $(\mathfrak{f}, 201$ & ices) & & & \\
\hline Men & 7 & 6.7 & -4 & 6.6 & 6.1 & -8 \\
\hline Women & 6.5 & 6.4 & -0.8 & 6.1 & 6.1 & -0.7 \\
\hline $\mathrm{AHC}$ in & ek, 2015 & prices) & & & & \\
\hline Median & 437 & 465 & 6 & 339 & 360 & 6 \\
\hline P10 & 175 & 180 & 3 & 165 & 154 & -7 \\
\hline Non-per & $(£ 000 \mathrm{~s}$ & minal) & & & & \\
\hline Median & 155 & 173 & 12 & 126 & 117 & -7 \\
\hline $\mathrm{P} 10$ & 8 & 11 & 35 & 6 & 7 & 19 \\
\hline
\end{tabular}

Sources: Authors' analysis of LFS and FRS/HBAI; ONS/CASE analysis of WAS.

Notes: Definitions of 'disability' vary between the three surveys. 'Disabled' categories are: hourly pay, 'Disability Discrimination Act' and 'Work Limiting Disabled ('not disabled' is neither); AHC income, 'disabled' are adults reporting a limiting long-standing illness or disability; non-pension wealth, 'disabled' are households with at least one individual with an activity limiting disability or long-standing illness. LFS and FRS figures are for UK; WAS figures are for GB. 


\section{Summary}

In contrast to the consistent patterns by age examined in Section 4, those we observe comparing population groups defined in other ways are much more complex, often with contrasts between the worst-off within each type and those with median or higher resources. We identify a number of groups who did particularly badly in different respects during the slow-growth decade from 2005 to 2015 . These include:

- The incomes of the poorest lone-parents;

- The incomes after housing costs of the poorest Londoners;

- Median household wealth in the East Midlands and North East;

- The incomes of the poorest social tenants;

- Median incomes and wealth of Black African households; and

- Disabled individuals and households in general, especially the wages of disabled women and the incomes of the poorest disabled adults.

\section{CONCLUSIONS}

The two decades from 1995 to 2015 in the UK were marked by both economic and political drama. The first half had steady growth in living standards, but this broke down with the financial and economic crisis of 2007-2008. A left-of-centre Labour government with redistributive policies from 1997 gave way in 2010 to a Conservative-led Coalition government which embarked on policies of retrenchment and 'austerity' in (selected) public services and working-age cash benefits. ${ }^{16}$ By the end, 'inequality' had become a more prominent public concern.

And yet on the face of it, the two decades after 1995-96 had much greater stability in economic inequality across the bulk of the population than the preceding period from the late 1970s, when income and earnings inequalities leapt dramatically. Although at the very top the income share of the top 1 per cent was much higher in 2015 than twenty years earlier, other measures of income inequality ended close to where they started (although with some year-to-year variation, notably in the years immediately after the economic crisis).

Why then did inequality become more salient? One reason was that there was such a contrast between the two decades in overall growth in wages and living standards. In retrospect it is easy to forget how much they rose in the first, and therefore how great the contrast was with the second decade of near-stagnation. It is one thing politically for there to be high (or even rising) inequality, if accompanied by growth. It is quite another for inequality to be maintained on an historically high plateau while accompanied by stagnation.

The second aspect which we have dived into is that this apparently calm surface at the population level masks substantial change, looking more deeply at differences between groups defined in different ways. Some of those differences apply across groups, from their poorest to their best-off members, but others are more subtle, with particular parts of their

\footnotetext{
${ }^{16}$ See Hills, Sefton and Stewart (2009) for detailed policy discussion of the Labour period and Hills, De Agostini and Sutherland (2016) of the Coalition period.
} 
distributions having done much worse than others, particularly after 2005. For those lagging behind what were very slow overall improvements, this meant absolute losses.

A major social change was the sharp decline in fortunes of younger people in pay, income and wealth after 2005 compared to older people. This decline was pervasive, affecting better- and worse off within younger age groups, and affected wages, incomes and wealth (although the incomes of the poorest 60-64 year-olds and poorest over-80s fell after 2005-06). For groups defined in other ways, the pattern was more complex, and does not correspond to simple ideas of who had been 'left behind' before the 2016 Brexit vote, but reveals how some gained and others lost substantially.

The apparent 'stability' in income inequality, at least, over the period is therefore something of a mirage: the nature and depth of economic inequalities have changed markedly for some groups even if overall levels remained relatively stable.

\section{REFERENCES}

Alvaredo, F., Atkinson, A.B., and Morelli, S (2015), The challenge of measuring UK wealth inequality in the 2000s, III Working Paper 4, London: London School of Economics [LSE].

Beatty, C. and Fotherhill, S. (2016), The contemporary labour market in Britain's older industrial towns, Sheffield: CRESR, Sheffield Hallam University.

Belfield, C., Blundell, R., Cribb, J. and Joyce, R. (2017), 'Two decades of income inequality in Britain: The role of wages', Economica, 84, 334, 157-179.

Burkhauser, R.V., Hérault, N., Jenkins, S.P., and Wilkins, R. (2018), 'Top incomes and inequality in the UK: Reconciling estimates from household surveys and tax return data', Oxford Economic Papers, 70, 2, 301-326.

Clarke, S. and Gregg, P. (2018), Count the pennies: Explaining a decade of lost pay growth, London: Resolution Foundation.

DWP [Department for Work and Pensions] (2018), Households Below Average Income: An analysis of the UK income distribution 1994/95 to 2016/17, London: DWP.

https://assets.publishing.service.gov.uk/government/uploads/system/uploads/attachment_data /file/691917/households-below-average-income-1994-1995-2016-2017.pdf.

Hills, J., Brewer, M., Jenkins, S., Lister, R., Lupton, R., Machin, S., Mills, C., Modood, T., Rees, T. and Riddell, S. (2010), An Anatomy of Economic Inequality, Report of the National Equality Panel, CASE report 60, London: LSE.

Hills, J., Cunliffe, J., Obolenskaya, P. and Karagiannaki, E. (2015), Falling Behind, Getting Ahead: The changing structure of inequality in the UK, 2007-2013, Social Policy in a Cold Climate Research Report 5, CASE, LSE.

Hills, J., De Agostini, P. and Sutherland, H. (2016), 'Benefits, tax credits and pensions' in R. Lupton, T. Burchardt, J. Hills, K. Stewart and P. Vizard (eds) Social Policy in a Cold Climate: Policies and their consequences since the crisis, Bristol: The Policy Press. 
Hills, J., Sefton, T. and Stewart, K. (eds) (2009), Towards a More Equal Society: Poverty, inequality and policy since 1979, Bristol: The Policy Press.

Intergenerational Commission (2018), A New Generational Contract: The final report of the Intergenerational Commission, London: Resolution Foundation.

Karagiannaki, E. (forthcoming) "Distout: Undertaking distributional analysis of continuous outcome variables: STATA programme and associated help file" STATA programme (distout.ado), help file (distout.doc)

Machin, S. (2011), 'Changes in UK wage inequality over the last forty years', in P. Gregg and J. Wadsworth (eds), The Labour Market in Winter: The state of working Britain, Oxford: Oxford University Press.

McKnight, A. (2014), Disabled people's financial histories: Uncovering the disability wealth-penalty, CASE paper 181, London: LSE

OECD [Organisation for Economic Co-operation and Development] (2015), In it together: Why less inequality benefits all, Paris: OECD.

ONS [Office for National Statistics] (2018), Wealth in Great Britain Wave 5: 2014 to 2016, London: ONS.

ONS (2019), Effects of taxes and benefits: disposable, dataset released 26 February 2018, London: ONS

https://www.ons.gov.uk/peoplepopulationandcommunity/personalandhouseholdfinances/inco meandwealth/datasets/householddisposableincomeandinequality

Sunday Times (2018), Rich List 2018, London: Sunday Times. 